\title{
Lead Speciation and Bioavailability in Apatite-Amended Sediments
}

\author{
Kirk G. Scheckel, ${ }^{1}$ Aaron G. B. Williams, ${ }^{2}$ Gregory Mc Dermott, ${ }^{3}$ David Gratson, ${ }^{3}$ \\ Dean Neptune, ${ }^{3}$ and James A. Ryan ${ }^{1}$
}

${ }^{1}$ USEPA, 5995 Center Hill Avenue, Cincinnati, OH 45224, USA

${ }^{2}$ Eastern Research Group, Inc., 10200 Alliance Road, Suite 190, Cincinnati, OH 45242, USA

${ }^{3}$ Neptune and Company, Inc., 8962 Spruce Ridge Road, Fairfax Station, VA 22039, USA

Correspondence should be addressed to Kirk G. Scheckel, scheckel.kirk@epa.gov

Received 19 July 2010; Accepted 25 November 2010

Academic Editor: Marco Trevisan

Copyright ( $) 2011$ Kirk G. Scheckel et al. This is an open access article distributed under the Creative Commons Attribution License, which permits unrestricted use, distribution, and reproduction in any medium, provided the original work is properly cited.

\begin{abstract}
The in situ sequestration of lead $(\mathrm{Pb})$ in sediment with a phosphate amendment was investigated by $\mathrm{Pb}$ speciation and bioavailability. Sediment $\mathrm{Pb}$ in preamendment samples was identified as galena $(\mathrm{PbS})$ with trace amounts of absorbed $\mathrm{Pb}$. Sediment exposed to atmospheric conditions underwent conversion to hydrocerussite and anglesite. Sediments mixed with apatite exhibited limited conversion to pyromorphite, the hypothesized end product. Conversion of $\mathrm{PbS}$ to pyromorphite is inhibited under reducing conditions, and pyromorphite formation appears limited to reaction with pore water $\mathrm{Pb}$ and $\mathrm{PbS}$ oxidation products. Porewater $\mathrm{Pb}$ values were decreased by $94 \%$ or more when sediment was amended with apatite. The acute toxicity of the sediment $\mathrm{Pb}$ was evaluated with Hyalella azteca and bioaccumulation of $\mathrm{Pb}$ with Lumbriculus variegatus. The growth of $H$. azteca may be mildly inhibited in contaminated sediment, with apatite-amended sediments exhibiting on average a higher growth weight by approximately $20 \%$. The bioaccumulation of $\mathrm{Pb}$ in L. variegatus tissue decreased with increased phosphate loading in contaminated sediment. The study indicates limited effectiveness of apatite in sequestering $\mathrm{Pb}$ if present as $\mathrm{PbS}$ under reducing conditions, but sequestration of porewater $\mathrm{Pb}$ and stabilization of near-surface sediment may be a feasible and alternative approach to decreasing potential toxicity of $\mathrm{Pb}$.
\end{abstract}

\section{Introduction}

Sediments pose a risk to human and ecological receptors in many watersheds throughout the United States and globally due to accumulation of chemicals of anthropogenic origin. The accumulation of chemicals is a result of both the deposition environment and the sorption properties exhibited by sediments. Consequently, each year many millions of cubic meters of sediment are dredged in the nation's waters to improve ecological habit and mitigate risk [1]. Tradition remediation strategies for contaminated sediments call for removal of sediments through dredge operations with containment of dredged material in landfills or capping resulting in both high capital cost and risk of unintentional releases. Due to the cost and risk associated with tradition sediment remediation approaches, the U.S.
Environmental Protection Agency (US EPA) identified in its Contaminated Sediment Management Strategy the goal of developing scientifically sound sediment management tools for use in sediment source control and remediation [2]. One approach identified is the in situ stabilization of metals that both reduce metal mobility and bioavailability.

Metal mobility and bioavailability can be decreased in situ through the application of amendments that sequester metals through sorption processes or mineralization. One of the most effective metal sequestration agents is phosphorus which acts as a natural scavenger for cationic metals and is readily available from the mineral apatite [3]. Demonstration of in situ stabilization of cationic metals in soils, in particular lead $(\mathrm{Pb})$, zinc $(\mathrm{Zn})$, and cadmium $(\mathrm{Cd})$, has been verified at a number of sites [4-7]. Laperche et al. [8] have shown direct physical evidence of the formation of pyromorphite, an 
extremely insoluble lead phosphate mineral, when synthetic apatite was added to $\mathrm{Pb}$ contaminated soils. Other heavy metals ( $\mathrm{Cd}, \mathrm{Zn}$ ) have also been studied with considerable success in reducing their bioavailability in soil when amended with apatite $[9,10]$. The success of these trials in soil is attributed to the very low solubility of metal phosphate minerals [11]. However, in situ stabilization of metals in sediments has not been widely applied and evaluated with apatite.

To support the US EPA goal of developing scientifically sound tools to remediate sediments, the in situ stabilization of sediment $\mathrm{Pb}$ was studied on the shore of Chopawamsic Creek, located on the Marine Corps Base Quantico (MCB Quantico) in Quantico, Virginia. Chopawamsic Creek drains a 12,000-acre watershed entirely within the boundaries of MCB Quantico and has been identified as a valuable nursery area for commercial and sport fish by the Virginia Institute of Marine Science. The source of $\mathrm{Pb}$ in Chopawamsic Creek is identified as a former firing range that was remediated by removal $\mathrm{Pb}$ shot and $\mathrm{Pb}$ contaminated soil. The former firing range contains numerous small streams and drainage points which are released to Chopawamsic Creek that reasonably accounts for the overland transport of $\mathrm{Pb}$.

The objective of this pilot demonstration project was to evaluate the efficacy of using apatite to sequester and stabilize $\mathrm{Pb}$ in the Chopawamsic Creek sediments. The objective will be assessed by (i) evaluating $\mathrm{Pb}$ speciation in sediments prior to and after addition of apatite, (ii) measuring $\mathrm{Pb}$ and phosphate concentrations in sediment pore water, and (iii) performing biological assays to determine the toxicity and bioaccumulation of the sediment $\mathrm{Pb}$ after addition of amendments.

\section{Materials and Methods}

2.1. Field Plot Design and Apatite Amendment. The pilot demonstration plots were located along the northern shore of Chopawamsic Creek approximately $1.6 \mathrm{~km}$ from the confluence with the Potomac River. Sample locations were selected based on historical data as well as exploratory sampling performed prior to plot preparation. Exploratory sampling detected sediment $\mathrm{Pb}$ ranging from 490-750 milligrams per kilogram $\left(\mathrm{mg} \mathrm{kg}^{-1}\right.$ ) (wet weight basis). All exploratory and pilot test sampling was completed during low tide, with minimal standing water.

The study design called for five plots that measure approximately $1.5 \mathrm{~m} \times 1.5 \mathrm{~m}\left(2.25 \mathrm{~m}^{2}\right)$ by $20 \mathrm{~cm}$ deep $\left(0.45 \mathrm{~m}^{3}\right.$ plot volume $)$. Plots $\mathrm{A}$ and $\mathrm{B}$ were uncontaminated reference sediments located upstream from the known area of contamination. Plot A received no treatment while Plot $\mathrm{B}$ was treated with $3 \%$ phosphorus (as apatite) by mass for the plot volume. Plots C, D, and E were located in the contaminated portion of Chopawamsic Creek. Plot D received no treatment while Plots $C$ and $E$ were treated with $1.5 \%$ and $3 \%$ phosphorus as apatite by mass for the plot volume, respectively. The apatite used in this demonstration has the trade name Phosfil from PCS Phosphate (a division of Potash Corporation, Aurora, NC). The material has a phosphate level of approximately 20\% (as $\mathrm{P}_{2} \mathrm{O}_{5}$ ) equivalent to $8.7 \%$ phosphorus. The $3 \%$ phosphorus loading required $290 \mathrm{~kg}$ of apatite; the $1.5 \%$ phosphorus loading required $145 \mathrm{~kg}$ of apatite for the plot volume assuming a sediment density of approximately 1.9 grams per centimeter cubed $\left(\mathrm{g} / \mathrm{cm}^{3}\right)$. Prior to apatite application, the plots were staked out, the vegetation cut down, and the sediment material was mixed and presampled. Following the initial sampling, apatite was distributed evenly across the plot dimension. A rototiller was then operated across the plot to mix the apatite down to a depth of approximately $20 \mathrm{~cm}$, with mixing accomplished by running the machine in three directions across the full width of each plot.

Preamendment samples were analyzed for sediment composition (i.e., total organic carbon, silt, sand and clay content). Total $\mathrm{Pb}$, pore water $\mathrm{Pb}$, and pore water orthophosphate (ortho-P) were determined via inductively coupled plasma mass spectrometry (ICP-MS; Perkin Elmer). Postamendment samples were collected 90 days after amendment application to allow suitable time for reaction to occur, similar to previous soil- $\mathrm{Pb}$ phosphate amendment studies [4]. The postamendment samples were evaluated for the same criteria as preamendment samples and also for biotoxicity and bioaccumulation. Composite samples from each test plot were used to measure the hypothesized effects of reduction in bioavailability using the following endpoints: (1) bioaccumulation in tissue of Lumbriculus variegatus (28day test) and (2) growth and survival of Hyalella azteca (28 day test). Approximately $26.5 \mathrm{~L}$ of sediment (with porewater) were collected at each test plot for the bioassays. A secondary postamendment sampling consisted of collecting the top $0.5 \mathrm{~cm}$ layer of sediment (noted as Plots C, D, and E-Top layer) due to the visual observation of a reddish-orange color of this particular layer that was not consistent with the lower portion of the sediment profile. The Top layer samples may represent the primary contact media for a variety of aquatic organisms and migratory water fowl.

In addition, a composite sample was collected from the firing range source soil to determine if the original soil- $\mathrm{Pb}$ speciation was retained in the sediment environment. The sample was sieved to $<2 \mathrm{~mm}$ to remove coarse soil material and bullet fragments and further processed in the laboratory to $<250 \mu \mathrm{m}$ fraction for analysis.

2.2. X-Ray Absorption Spectroscopy (XAS). Pb L LII-edge (13 $035 \mathrm{eV}) \mathrm{X}$-ray absorption spectra were collected at beamlines PNC/XSD 20-BM and MRCAT 10-ID at the Advanced Photon Source at Argonne National Laboratory, Argonne, IL. The electron storage ring was operated in top-up mode at $7 \mathrm{GeV}$. Spectra were collected in both transmission and fluorescence modes with a 13-element solid-state detector at room temperature. For each sample, a total of three to five scans were collected and averaged. Data were analyzed using the Athena software program [12]. The results for the samples were compared with those from synthesized minerals and mineral specimens acquired from the Smithsonian National Museum of Natural History (USA). All minerals were verified with XRD before use as reference materials for assessment of $\mathrm{Pb}$ solid-state speciation. 
Sediment $\mathrm{Pb}$ speciation was determined by comparison of $\mathrm{Pb}$ standards to the field samples by Linear Combination Fitting (LCF). LCF refers to the process of selecting a multiple component fitting function with a least-squares algorithm that minimizes the sum of the squares of residuals. A fit range of -20 to $100 \mathrm{eV}$ was utilized for the X-ray absorption near-edge structure (XANES) portion of the XAS spectra which encompassed 240 data points and up to five variables. The best fitting scenarios are determined by the smallest residual error $\left(\chi^{2}\right)$ and the sum of all component fractions being close to 1 . A minimum of 2 components were necessary to fully describe any particular sample within $1 \%$ reproducible error indicating that two $\mathrm{Pb}$ species were tested statistically stringent. The reference samples included for LCF were galena $(\mathrm{PbS})$, hydrocerussite $\left(\mathrm{Pb}_{3}\left(\mathrm{CO}_{3}\right)_{2}(\mathrm{OH})_{2}\right)$, adsorbed $\mathrm{Pb}$ (as $\mathrm{PbNO}_{3}$ sorbed to ferrihydrite at $\mathrm{pH}$ 6), chloropyromorphite $\left(\mathrm{Pb}_{5}\left(\mathrm{PO}_{4}\right)_{3} \mathrm{Cl}\right)$, and anglesite $\left(\mathrm{PbSO}_{4}\right)$. In general, LCF results are accurate to $\pm 5 \%$, thus results less that $10 \%$ weight contribution should be interpreted with caution even though these components improve the overall error within the fitting process.

2.3. Bioassay Testing. Composite sediment samples from each of the five plots were collected 90 days after amendment addition and prepared for bioassay tests according to the procedures and methods outlined by US EPA guidance documents $[2,13]$. The procedure measures chronic toxicity through direct sediment exposure to the freshwater amphipod, $H$. azteca, over a 28-day period and bioaccumulation of $\mathrm{Pb}$ in the tissue of $\mathrm{L}$. variegatus, also during a 28day period. For the acute toxicity test with $H$. azteca, a composite sediment sample from each plot of sufficient volume was collected, mixed, and split between 12 replicate tanks with 10 organisms per tank. Therefore, 12 mean survival responses and 12 mean growth responses were obtained to evaluate each composite sediment sample for each of the five plots. For the bioaccumulation test using L. variegatus, a preliminary four-day toxicity screening test was performed to determine if $L$. variegatus would survive and exhibit normal behavior, for example, burrow into the sediment [13]. Based on the survival and normal behavior of the $L$. variegatus worms in the preliminary test, a 28-day bioaccumulation study was performed as detailed in US EPA guidance documents $[2,13]$. Briefly, approximately $5 \mathrm{~g}$ (wetweight) of $L$. variegatus was measured and recorded before being placed into replicates glass tanks, twelve replicates for each of the five sediment test plots. At the end of the 28day period, $L$. variegatus was allowed to depurate for 24 hours in clean water before being analyzed for $\mathrm{Pb}$ tissue concentrations [13]. Ammonia, temperature, $\mathrm{pH}$, dissolved oxygen, hardness, alkalinity, conductivity, and oxygen were measured during the test periods for both the survivability and bioaccumulation tests to account for these potential effects on the organisms in addition to the toxicity of $\mathrm{Pb}$. A laboratory control sediment consisting of quartz sand with test required nutrients was used to observe health affects in the absence of Chopawamsic Creek sediment for both the $H$. azteca and L. variegatus bioassay tests. The bioassays results were evaluated with a Dunnett's Test which compared all test plots to control plots followed by multiple comparisons between test plots.

\section{Results and Discussion}

3.1. Test Plot Characterization. Sediment properties for the test plots and amendment design are provided in Table 1. Both uncontaminated (Plots A and B) and contaminated (Plots C, D, and E) plots exhibited a similar proportion of sand, silt, clay, and total organic carbon (TOC) with the plots comprising almost entirely of clay and silt. The TOC for all plots ranged from $13.2 \%$ to $20.3 \%$ (Table 1). Table 2 provides the preamendment sediment $\mathrm{Pb}$ concentration and pore water $\mathrm{Pb}$ and ortho- $\mathrm{P}$ concentration for each test plot. Plots A and B exhibited sediment $\mathrm{Pb}$ concentrations of 122 and 132 milligrams per kilogram-dry weight $\left(\mathrm{mg} \mathrm{kg}^{-1}-\mathrm{dw}\right)$, whereas Plots $\mathrm{C}, \mathrm{D}$, and E exhibited sediment $\mathrm{Pb}$ concentrations of 2,930, 1,763, and $2,993 \mathrm{mg} \mathrm{kg}^{-1}-\mathrm{dw}$, respectively. The contaminated plots exceed the standard clean-up value applied for human risk based on the Integrated Exposure Uptake and Biokinetic (IEBEK) Model (400 $\left.\mathrm{mg} \mathrm{kg}^{-1}-\mathrm{dw}\right)$ and exceed both the EPA Ecological Screening Value $\left(1,700 \mathrm{mg} \mathrm{kg}^{-1}-\mathrm{dw}\right)$ and fresh water sediment benchmarks provided by the Nation Oceanic and Atmospheric Administration (NOAA) Screening Quick Reference Tables (SQuiRTs). Consistent with the sediment $\mathrm{Pb}$ concentrations, $\mathrm{Pb}$ pore water values were marked between contaminated and uncontaminated plots. Plots A and B exhibited sub-microgram per liter $\left(\operatorname{ug~L}^{-1}\right)$ pore water concentrations, whereas the contaminated plots exhibit levels of 11.3 to $20.7 \mathrm{ug} \mathrm{L}^{-1}$ (Table 2). These concentrations are above US EPA Maximum Contaminant Levels (MCLs) for human consumption and exceed NOAA SQuiRT values. Preamendment pore water ortho-P levels were similar for all plots ranging from 7 to $30 \mathrm{ug} \mathrm{L}^{-1}$ (Table 2).

Ninety days after amendment addition sediment $\mathrm{Pb}$ values for Plot C, D, and E were within approximately $20 \%$ of their preamendment concentration with Plots $\mathrm{C}$ and $\mathrm{E}$, which received apatite, at $1.5 \%$ and $3 \%$ phosphorus loadings, respectively, both exhibiting an increased in sediment $\mathrm{Pb}$ (Table 2). The unamended contaminated plot, Plot D, exhibited a minor reduction in sediment $\mathrm{Pb}$ (Table 2). The increase in sediment $\mathrm{Pb}$ in Plots $\mathrm{C}$ and $\mathrm{E}$ may be partly influenced by the sequestration of $\mathrm{Pb}$ since the objective of in situ stabilization is to immobilize and sequester the contaminant of concern; therefore, the overall concentration of the contaminant does not diminish as a result of treatment. In fact, overall contaminant concentration in the sediment may increase due to the sequestration of metals as additional mass is transported through the amended sediments and the contaminant selectively partitions to a solid phase (i.e., the apatite). It is also plausible that the change is attributed simply to the inherent variability of working with natural systems in field studies. The alteration of the sediment structure due to rototilling the plots and subsample selection for composites between the preamendment and postamendment collection also provide for a degree of variability due to changes in sediment density. 
TABLE 1: Chopawamsic Creek sediment experimental plot contamination identification and amendment rate along with texture and organic carbon characteristics.

\begin{tabular}{lcccccccc}
\hline Sample & Pb contaminated & Amendment & Sand $(\%)$ & Silt $(\%)$ & Clay $(\%)$ & TOC $(\%)$ & pH & Redox potential (mV) \\
\hline Plot A & No & None & 1.8 & 52.1 & 46.2 & 18.7 & 6.27 & -277.6 \\
Plot B & No & 3\% P apatite & 0.3 & 33.7 & 66.0 & 20.4 & 6.16 & -276.7 \\
Plot C & Yes & 1.5\% P apatite & 0.1 & 41.7 & 58.3 & 13.2 & 6.22 & -276.2 \\
Plot D & Yes & None & 0.3 & 34.4 & 65.3 & 20.3 & 6.37 & -269.4 \\
Plot E & Yes & 3\% P apatite & 0.1 & 24.6 & 75.3 & 17.9 & 6.28 & -261.2 \\
\hline
\end{tabular}

TABle 2: Chopawamsic Creek sediment $\mathrm{Pb}$, pore water $\mathrm{Pb}$, and ortho- $\mathrm{P}$ concentrations for preamendment and postamendment experimental plots.

\begin{tabular}{|c|c|c|c|c|c|c|}
\hline \multirow{2}{*}{ Sample } & \multicolumn{3}{|c|}{ Preamendment } & \multicolumn{3}{|c|}{ Postamendment } \\
\hline & Sed $\mathrm{Pb}^{(\mathrm{a})} \mathrm{mg} \mathrm{kg}^{-1}$ & $\mathrm{PW} \mathrm{Pb}^{(\mathrm{b})} \mu \mathrm{g} \mathrm{L}^{-1}$ & Ortho-P mg L ${ }^{-1}$ & Sed $\mathrm{Pb} \mathrm{mg} \mathrm{kg}^{-1}$ & $\mathrm{PW} \mathrm{Pb} \mu \mathrm{g} \mathrm{L}^{-1}$ & Ortho-P mg L $\mathrm{L}^{-1}$ \\
\hline Plot A & 122 & 0.042 & 0.030 & 114 & 0.098 & 0.002 \\
\hline Plot B & 132 & 0.113 & 0.020 & 44 & 0.042 & 0.002 \\
\hline Plot C & 2930 & 16.100 & 0.007 & 3680 & 0.903 & 0.002 \\
\hline Plot D & 1763 & 11.300 & 0.020 & 1390 & 0.501 & 0.005 \\
\hline Plot E & 2993 & 20.700 & 0.009 & 3390 & 0.513 & 0.002 \\
\hline
\end{tabular}

${ }^{(a)}$ Sediment $\mathrm{Pb}$ concentration determined on a dry weight basis by microwave-assisted acid digestion (EPA Method 3051). ${ }^{\text {(b) }}$ Porewater Pb concentration determined by ICP-MS.

Postamendment $\mathrm{Pb}$ pore water concentrations in Plots $\mathrm{A}$ and $\mathrm{B}$ were consistent with preamendment values. However, pore water $\mathrm{Pb}$ in the contaminated plots, Plots $\mathrm{C}, \mathrm{D}$, and $\mathrm{E}$, was significantly lower in the postamendment testing, exhibiting a $94-98 \%$ decrease compared to the preamendment concentration. It is noted that Plot D, which was not amended with $\mathrm{P}$, also exhibited a decrease in pore water $\mathrm{Pb}$ consistent with the amended plots. The cause of the decease in pore water $\mathrm{Pb}$ in Plot $\mathrm{D}$ is unknown and may represent an experimental sampling error or unaccounted for natural variable, but $\mathrm{Pb}$ speciation data and the bioassay results indicate differenced exist between $\mathrm{Pb}$ in amended and unamended plots.

Ortho-P concentrations in sediment pore water were measured for in preamendment and postamendment samples for all plots. In each case, ortho-P concentrations were below the regulatory limit and actually decreased slightly in the postamendment plots receiving the phosphate amendment. This is consistent with the phosphate leaching characteristic of Phosfil, which exhibits a low leaching potential above $\mathrm{pH} 6$ [14].

3.2. Synchrotron Pb Speciation. XANES analysis of Plots A and $\mathrm{B}$ (noncontaminated plots) was attempted but poor data quality (spectra not shown) due to low $\mathrm{Pb}$ concentrations resulted in no useful information for both the preamendment and postamendment samples (Note: these control plots are intended to evaluate the effect of the amendment on benthic arthropods in the absence of harmful $\mathrm{Pb}$ levels). Spectra for preamendment samples from Plots C, D, and E are provided in Figure 1. Spectra are shown for both samples maintained in an anoxic environment and for samples allowed to oxidize under atmospheric conditions. Oxidized samples were evaluated to identify potential changes in
$\mathrm{Pb}$ speciation during low tide or seasonal dry periods. In addition, Figure 1 provides a spectrum obtained for the Hillside Source which represents the $\mathrm{Pb}$ speciation from the firing range soil responsible for contamination of the Chopawamsic Creek sediments. LCF evaluation (fit shown as red circles superimposed over the collected spectra) of the XANES spectra is also provided in Figure 1 with a summary of the results provided in Table 3 . $\mathrm{Pb}$ minerals identified from the LCF process are also shown for reference.

The source material represented by the Hillside Source sample exhibited $\mathrm{Pb}$ species of adsorbed $\mathrm{Pb}(64 \%)$ and hydrocerussite $(36 \%)$ which are common species found in $\mathrm{Pb}$ contaminated soils. In contrast, sediment $\mathrm{Pb}$ in preamendment samples occurs almost entirely as $\mathrm{PbS}$. PbS accounts for $94 \%$ to $100 \%$ of the sediment lead in Plots $\mathrm{C}, \mathrm{D}$, and $\mathrm{E}$ with minor amounts of adsorbed $\mathrm{Pb}$. Given the geochemical conditions of the sediment, specifically the $\mathrm{pH}$ and redox values (Table 1), formation of $\mathrm{PbS}$ from the Hillside Source material of adsorbed $\mathrm{Pb}$ and hydrocerussite is probable in the low redox sediment environment $[15,16]$. Upon exposure to atmosphere conditions, $\mathrm{Pb}$ speciation is altered for samples collected from Plots C, D, and E (Figure 1). Oxidation resulted in reduction galena content (39-44\%) with appearance of hydrocerussite (46-61\%), with minor amounts of adsorbed $\mathrm{Pb}$ also observed for Plot E (Table 3). The results for the atmospheric exposed sediments demonstrate that sediment $\mathrm{Pb}$ may undergo a reversible conversion to hydrocerussite if removed from a stable reducing environment due to events such as dry periods, redeposition to high ground, or disturbance during dredging operations.

$\mathrm{Pb}$ speciation results of the postamendment samples are provided in Figure 2 and summarized in Table 3. In contrast to the preamendment samples which exhibited 94-100\% 
TABle 3: Chopawamsic Creek sediment $\mathrm{Pb}$ speciation by linear combination fitting (LCF) for preamendment and postamendment experimental plot samples.

\begin{tabular}{|c|c|c|c|c|c|c|}
\hline \multirow{2}{*}{ Sample } & \multicolumn{5}{|c|}{ LCF-weighted contributions (\%) } & \multirow{2}{*}{$\begin{array}{c}\text { Error } \\
\chi^{2 a}\end{array}$} \\
\hline & Galena & Hydrocerussite & Adsorbed $\mathrm{Pb}$ & Pyromorphite & Anglesite & \\
\hline \multicolumn{7}{|l|}{ Preamendment } \\
\hline Plot C & 98 & & 2 & & & 0.003 \\
\hline Plot D & 94 & & 6 & & & 0.001 \\
\hline Plot E & 100 & & & & & 0.004 \\
\hline Plot C-Oxidized & 44 & 56 & & & & 0.003 \\
\hline Plot D-Oxidized & 39 & 61 & & & & 0.011 \\
\hline Plot E-Oxidized & 44 & 46 & 10 & & & 0.002 \\
\hline Hillside source & & 36 & 64 & & & 0.005 \\
\hline \multicolumn{7}{|l|}{ Postamendment } \\
\hline Plot C & 59 & & 27 & 9 & 5 & 0.008 \\
\hline Plot D & 63 & & 34 & & 3 & 0.006 \\
\hline Plot E & 59 & & 34 & 6 & 1 & 0.006 \\
\hline Plot C-Top layer & 37 & & 26 & 25 & 12 & 0.017 \\
\hline Plot D-Top layer & 44 & 20 & 20 & & 16 & 0.009 \\
\hline Plot E-Top layer & 23 & & 42 & 33 & 2 & 0.006 \\
\hline
\end{tabular}

${ }^{(\mathrm{a})} \chi^{2}=\left[(\text { data }-\mathrm{fit})^{2}\right] /\left[\right.$ data $\left.^{2}\right]$.

$\mathrm{PbS}, \mathrm{PbS}$ content is markedly reduced in postamendment sediment from Plots $\mathrm{C}, \mathrm{D}$, and $\mathrm{E}$ (Table 3 ) ranging from $59 \%-63 \%$. After $\mathrm{PbS}$, adsorbed $\mathrm{Pb}$ is the most common species of $\mathrm{Pb}$ accounting for $27 \%$ to $34 \%$ of total sediment $\mathrm{Pb}$. All plots also exhibited a small percentage (1-5\%) of $\mathrm{PbSO}_{4}$, an oxidation product of $\mathrm{Pb}$ sulfides, and is a known conversion product of $\mathrm{PbS}$. The anticipated conversion product of sediment $\mathrm{Pb}$ due to the introduction of phosphate was pyromorphite; however, pyromorphite only accounts for $9 \%$ (Plot C) and 6\% (Plot E) of the total sediment $\mathrm{Pb}$ [15]. No pyromorphite was observed in the unamended plot (Plot $\mathrm{D})$. The low conversion rate of $\mathrm{Pb}$ to pyromorphite is likely driven by the stability of $\mathrm{PbS}$ in a low redox, high dissolved organic carbon environment $[16,17]$. The pyromorphite that formed in the test plots may be limited by more chemically available $\mathrm{Pb}$, either from aqueous $\mathrm{Pb}$ species in the sediment pore water or from oxidized $\mathrm{Pb}$ minerals [e.g., $\mathrm{PbSO}_{4}$ or $\left(\mathrm{Pb}_{3}\left(\mathrm{CO}_{3}\right)_{2}(\mathrm{OH})_{2}\right)$ ] and adsorbed $\mathrm{Pb}$.

The top layer samples were collected to evaluate potential differences between the top $0.5 \mathrm{~cm}$ of sediment, or nearsurface portion of the sediment, and the bulk sediment. The near surface sediment is anticipated to represent the portion of sediment more likely to be ingested by benthic arthropods or other marsh dwelling organisms. Plots $\mathrm{C}$ and E-Top layer, which received the apatite amendment, exhibited $\mathrm{PbS}$ and adsorbed $\mathrm{Pb}, \mathrm{PbSO}_{4}$, and pyromorphite consistent with the bulk samples. However, pyromorphite formation in the near surface sediment was considerably more abundant (25-33\%) compared to the bulk sediment (6-9\%) as was the $\mathrm{PbS}$ oxidation product $\mathrm{PbSO}_{4}(2-16 \%$ in top layer compared to $1-5 \%$ in bulk sediment). These results suggest that the oxidation of the sediment and therefore the destabilization of $\mathrm{PbS}$ may enhance the conversion of sediment $\mathrm{Pb}$ species to pyromorphite in the presence of apatite. In the absence of apatite (Plot D), no pyromorphite was formed, instead conditions favored the formation of hydrocerussite as an alternative or stable end product for $\mathrm{PbS}$ oxidation in the near surface sediment. Also noted in the near surface sediment was a reddish-brown precipitate. The precipitate was identified as an amorphous iron oxyhydroxide by Mössbauer spectroscopy (data not shown) along with pyritic (FeS) materials. The destabilization of $\mathrm{PbS}$ by oxidation also results in pyrite-like materials breaking down as well. This iron precipitate observation was more pronounced in the test plots and tended to occur only in areas where the sediment surface was above the water level.

3.3. Bioassay Results. Bioassay studies were performed with postamendment sediments to investigate $\mathrm{Pb}$ bioaccumulation in the tissue of $L$. variegatus, and growth and survival of $H$. azteca. In the noncontaminated Plots $\mathrm{A}$ and $\mathrm{B}, H$. azteca exhibited a minor mean differences for growth $(0.63-$ $0.71 \mathrm{mg}$ ) and survival (91.7-95.8\%) in which the apatite amended Plot B had the lower end of both measurements (Table 4). The outcome suggests apatite has minimal or no effect on the health of $H$. azteca based on these measured end points. The contaminated Plots $\mathrm{C}, \mathrm{D}$, and $\mathrm{E}$ also noted high survival rates ranging from $91.7-95 \%$; however, mean growth was lower for the unamended sediment in Plot D $(0.53 \mathrm{mg})$ in comparison to the apatite amendment sediment in Plots $\mathrm{C}$ and $\mathrm{E}(0.63-0.66 \mathrm{mg})$ (Table 4$)$. The results suggest that the contaminated sediments in Chopawamsic Creek are not overly detrimental to $\mathrm{H}$. azteca at the observed $\mathrm{Pb}$ concentrations and the experimental timeframe, but may reduce the organisms' overall health based on the observed growth endpoint. It is noted that the laboratory control 
TABle 4: Hyalella azteca survival and growth and Lumbriculus variegatus bioaccumulation data for Chopawamsic Creek sediment postamendment experimental plots.

\begin{tabular}{|c|c|c|c|c|c|c|c|c|c|}
\hline \multirow{3}{*}{ Sample } & \multicolumn{6}{|c|}{ Hyalella azteca survival and growth } & \multirow{2}{*}{\multicolumn{3}{|c|}{$\begin{array}{l}\text { Lumbriculus variegates bioaccumulation } \\
\qquad \text { Wet weight }\left(\mu \mathrm{g} \mathrm{g}^{-1}\right)\end{array}$}} \\
\hline & \multicolumn{3}{|c|}{ Percent survival } & \multicolumn{3}{|c|}{ Dry weight (mg) } & & & \\
\hline & Median & Mean & Std Dev & Median & Mean & Std Dev & Median & Mean & Std Dev \\
\hline Lab Control & 90 & 83.3 & 18.3 & 0.34 & 0.33 & 0.07 & 0.071 & 0.071 & 0.01 \\
\hline Plot A & 100 & 95.8 & 9.0 & 0.71 & 0.71 & 0.10 & 0.226 & 0.230 & 0.04 \\
\hline Plot B & 100 & 91.7 & 11.9 & 0.66 & 0.63 & 0.12 & 0.266 & 0.260 & 0.04 \\
\hline Plot C & 100 & 95.0 & 6.7 & 0.61 & 0.63 & 0.11 & 3.00 & 3.40 & 0.82 \\
\hline Plot D & 100 & 94.2 & 7.9 & 0.50 & 0.53 & 0.13 & 5.16 & 5.46 & 1.23 \\
\hline Plot E & 95 & 91.7 & 10.3 & 0.69 & 0.66 & 0.17 & 1.69 & 1.84 & 0.67 \\
\hline
\end{tabular}



FIGURE 1: XANES spectra and LCF of preamendment Chopawamsic Creek sediment and the firing range source soil (Hillside Source). Plots C-E samples were collected and stored under anaerobic conditions. Plots C-E-Oxidized samples were collected under anaerobic conditions and exposed to atmospheric air for one week prior to analysis. Plot $\mathrm{C}$ was amended with $1.5 \%$ phosphorus, Plot $\mathrm{D}$ was unamended, and Plot $\mathrm{E}$ was amended with 3\% phosphorus after the collection of these samples. LCF of the spectra are shown as red circles and $\mathrm{Pb}$ standards used in the fits are shown for comparison.

exhibited the poorest growth and survival for $H$. azteca ( $0.33 \mathrm{mg}$ for growth and $83 \%$ survival).

The effect of the apatite amendment was more discernable with regard to the bioaccumulation of $\mathrm{Pb}$ in L. variegatus tissue, specifically in the contaminated test plots. In the contaminated test plots, the mean tissue concentrations were $3.40 \mu \mathrm{gg}^{-1}$ in Plot C (1.5\% phosphorus), $1.84 \mu \mathrm{gg}^{-1}$

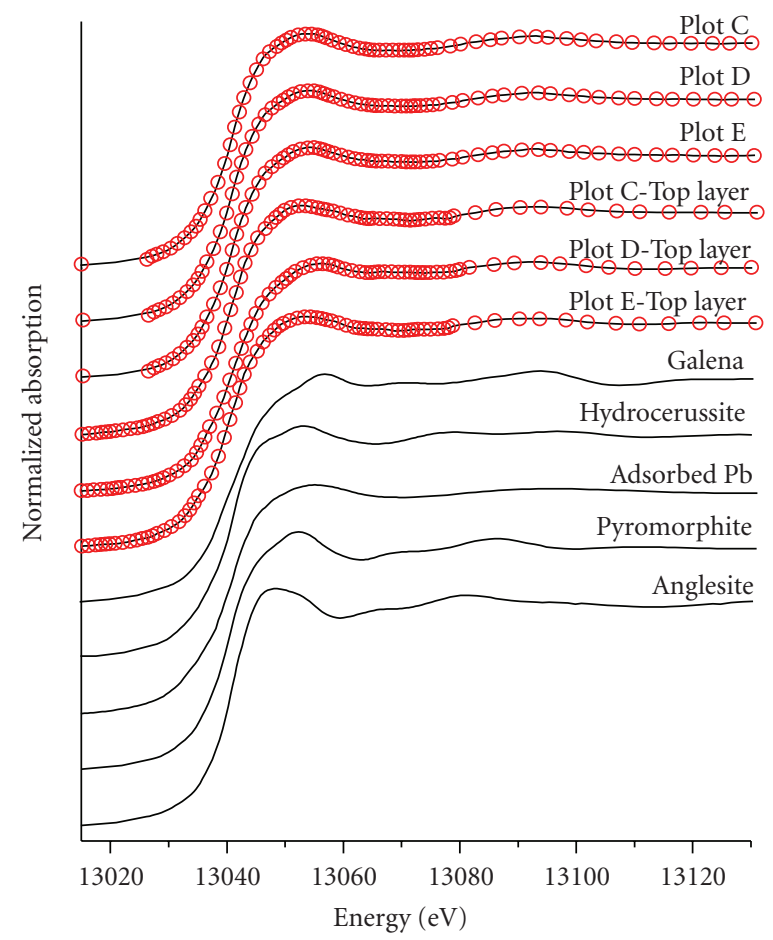

FIGURE 2: XANES spectra and LCF of postamendment Chopawamsic Creek sediment. Plots C-E samples were collected from the top $5-8 \mathrm{~cm}$ profile and stored under anaerobic conditions. Plots $\mathrm{C}-\mathrm{E}-$ Top layer samples were collected from the top $0.5 \mathrm{~cm}$ profile and stored under anaerobic conditions. Plot $\mathrm{C}$ was amended with $1.5 \%$ phosphorus, Plot D was unamended, and Plot $\mathrm{E}$ was amended with $3 \%$ phosphorus. LCF of the spectra are shown as red circles and $\mathrm{Pb}$ standards used in the fits are shown for comparison.

in Plot E (3\% phosphorus), and $5.46 \mu \mathrm{gg}^{-1}$ in Plot D (no phosphorus). The $\mathrm{Pb}$ tissue concentrations appear to be influenced by the presence or absence of apatite and possibly the phosphate loading rate. A possible cause of the higher tissue $\mathrm{Pb}$ concentration in the unamended sediments may be related to the occurrence of hydrocerussite, which was not observed in either Plot C or Plot E. Hydrocerussite is more soluble (therefore more bioavailable) than $\mathrm{PbS}$ based on solubility products [17]. The tissue concentrations do not correlate with the measured postamendment $\mathrm{Pb}$ pore water 
concentrations indicating that the solid-phase sediment $\mathrm{Pb}$ component in this study exhibits a more influential role on the health of the arthropods. In the noncontaminated Plots $\mathrm{A}$ and $\mathrm{B}$, mean $\mathrm{Pb}$ tissue concentrations of 0.230 and $0.260 \mu \mathrm{g} \mathrm{g}^{-1}$ were observed, respectively, with no apparent influence of the apatite in Plot $\mathrm{B}$ at low sediment $\mathrm{Pb}$ concentrations.

\section{Conclusions}

In this study, we examined the impact of apatite amendments on $\mathrm{Pb}$ biotoxicity and water quality in Chopawamsic Creek sediments impacted by $\mathrm{Pb}$ migration from a nearby shooting range site as well as noncontaminated control sediments. Postamendment samples saw a significant drop in pore water $\mathrm{Pb}$ concentrations, a 17- to 40 -fold decrease. Synchrotron XAS results identified discernible changes in $\mathrm{Pb}$ speciation from galena in the preamendment samples to galena, adsorbed $\mathrm{Pb}$, anglesite, and pyromorphite (only for the apatite amended plots). The sediment $\mathrm{Pb}$ species appears to be dependent on the sediment redox condition, with $\mathrm{Pb}$ existing as galena under reducing conditions in the bulk sediment and converting to oxidative species when exposed to atmospheric conditions, as observed for near surface sediment or sediment removed from the reducing marsh environment. The formation of pyromorphite is likely limited by the availability of pore water $\mathrm{Pb}$ or from more chemically available oxidized $\mathrm{Pb}$ species. Conversion of sediment $\mathrm{PbS}$, the most abundant form of $\mathrm{Pb}$ in the sediment, to pyromorphite is unlikely due to the stability of $\mathrm{PbS}$ under reducing conditions. Biotoxicity testing demonstrated no adverse effects of Chopawamsic Creek sediments to $H$. azteca, but $\mathrm{Pb}$ bioaccumulation increased from the noncontaminated plots to the apatite amended plots to finally the highest accumulation in the contaminated, unamended plot indicating a dose response in L. variegatus.

\section{Acknowledgments}

The U.S. Environmental Protection Agency through its Office of Research and Development funded and managed a portion of the research described here. It has not been subject to Agency review and therefore does not necessarily reflect the views of the Agency. No official endorsement should be inferred. This work was completed by the USEPA and Neptune \& Company under a joint U.S. Navy approved Quality Assurance Project Plan. Some samples, data collection, and analysis were completed by or directed by Neptune and Company. PNC/XSD facilities at the Advanced Photon Source, and research at these facilities, are supported by the US Department of Energy-Basic Energy Sciences, a Major Resources Support grant from NSERC, the University of Washington, Simon Fraser University and the Advanced Photon Source. Use of the Advanced Photon Source is also supported by the U. S. Department of Energy, Office of Science, Office of Basic Energy Sciences, under Contract DE-AC02-06CH11357. MRCAT operations are supported by the Department of Energy and the MRCAT member institutions.

\section{References}

[1] Tetra Tech NUS I, "Remedial Investigation Report for Site 100Chopawamsic Creek," Marine Corps Base Quantico, Va, USA, 2004.

[2] USEPA, "EPA's Contaminated Sediment Management Strategy," EPA-823-R-98-001, Cincinnati, Ohio, USA, 1998.

[3] K. G. Scheckel, R. L. Chaney, N. T. Basta, and J. A. Ryan, "Advances in assessing bioavailability of metal(loid)s in contaminated soils," Advances in Agronomy, vol. 104, pp. 1-52, 2009.

[4] J. A. Ryan, W. R. Berti, S. L. Brown et al., "Reducing children's risk to soil $\mathrm{Pb}$ : summary of a field experiment," Environmental Science \& Technology, vol. 38, no. 1, pp. 18A-24A, 2004.

[5] Tetra Tech NUS I, "Basewide Background Report," Marine Corps Combat Development Command. Engineering Field Activity Chesapeake, Naval Facilities Engineering Command, 2000.

[6] K. G. Scheckel and J. A. Ryan, "Spectroscopic speciation and quantification of lead in phosphate-amended soils," Journal of Environmental Quality, vol. 33, no. 4, pp. 1288-1295, 2004.

[7] K. G. Scheckel, J. A. Ryan, D. Allen, and N. V. Lescano, "Determining speciation of $\mathrm{Pb}$ in phosphate-amended soils: method limitations," Science of the Total Environment, vol. 350, no. 1-3, pp. 261-272, 2005.

[8] V. Laperche, S. J. Traina, P. Gaddam, and T. J. Logan, "Chemical and mineralogical characterizations of $\mathrm{Pb}$ in a contaminated sail: reactions with synthetic apatite," Environmental Science and Technology, vol. 30, no. 11, pp. 3321-3326, 1996.

[9] R. E. Hamon, M. J. McLaughlin, and G. Cozens, "Mechanisms of attenuation of metal availability in in situ remediation treatments," Environmental Science and Technology, vol. 36, no. 18, pp. 3991-3996, 2002.

[10] S. K. Porter, K. G. Scheckel, C. A. Impellitteri, and J. A. Ryan, "Toxic metals in the environment: thermodynamic considerations for possible immobilization strategies for $\mathrm{Pb}$, Cd, As, and Hg," Critical Reviews in Environmental Science and Technology, vol. 34, no. 6, pp. 495-604, 2004.

[11] K. G. Scheckel and J. A. Ryan, "Effects of aging and $\mathrm{pH}$ on dissolution kinetics and stability of chloropyromorphite," Environmental Science and Technology, vol. 36, no. 10, pp. 2198-2204, 2002.

[12] B. Ravel and M. Newville, "ATHENA, ARTEMIS, HEPHAESTUS: data analysis for X-ray absorption spectroscopy using IFEFFIT," Journal of Synchrotron Radiation, vol. 12, no. 4, pp. 537-541, 2005.

[13] USEPA, Methods for Measuring the Toxicity and Bioaccumulation of Sediment-Associated Contaminants with Freshwater Invertebrates, EPA, Duluth, Minn, USA, 1994.

[14] CICEET, "Pilot-scale reactive barrier technologies for containment of metal-contaminated sediments and dredged materials," Tech. Rep. 822 5/08, Durham, Durham, NH, USA, 2004.

[15] M. J. Marqués, E. Martínez-Conde, J. V. Rovira, and S. Ordóñez, "Heavy metals pollution of aquatic ecosystems in the vicinity of a recently closed underground lead-zinc mine (Basque Country, Spain)," Environmental Geology, vol. 40, no. 9, pp. 1125-1137, 2001.

[16] P. A. O’Day, S. A. Carroll, and G. A. Waychunas, "Rockwater interactions controlling zinc, cadmium, and lead concentrations in surface waters and sediments, U.S. Tri-State 
Mining 1. Molecular identification using X-ray absorption spectroscopy," Environmental Science and Technology, vol. 32, no. 7, pp. 943-955, 1998.

[17] W. L. Lindsay, Chemical Equilibria in Soils, John Wiley \& Sons, New York, NY, USA, 1979. 

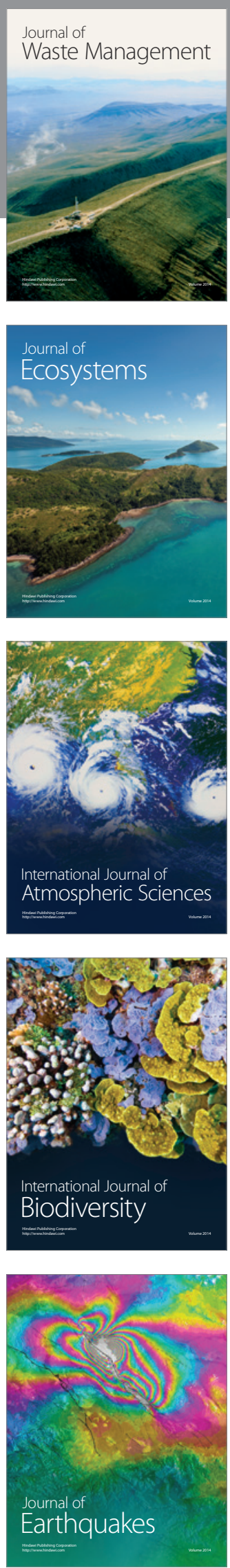
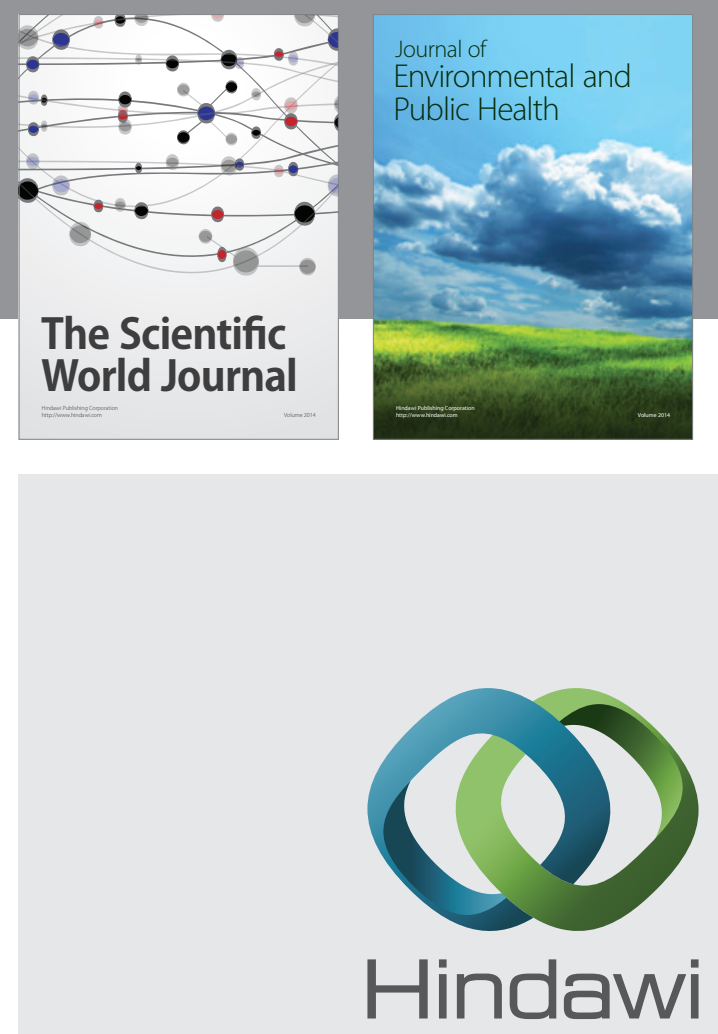

Submit your manuscripts at

http://www.hindawi.com

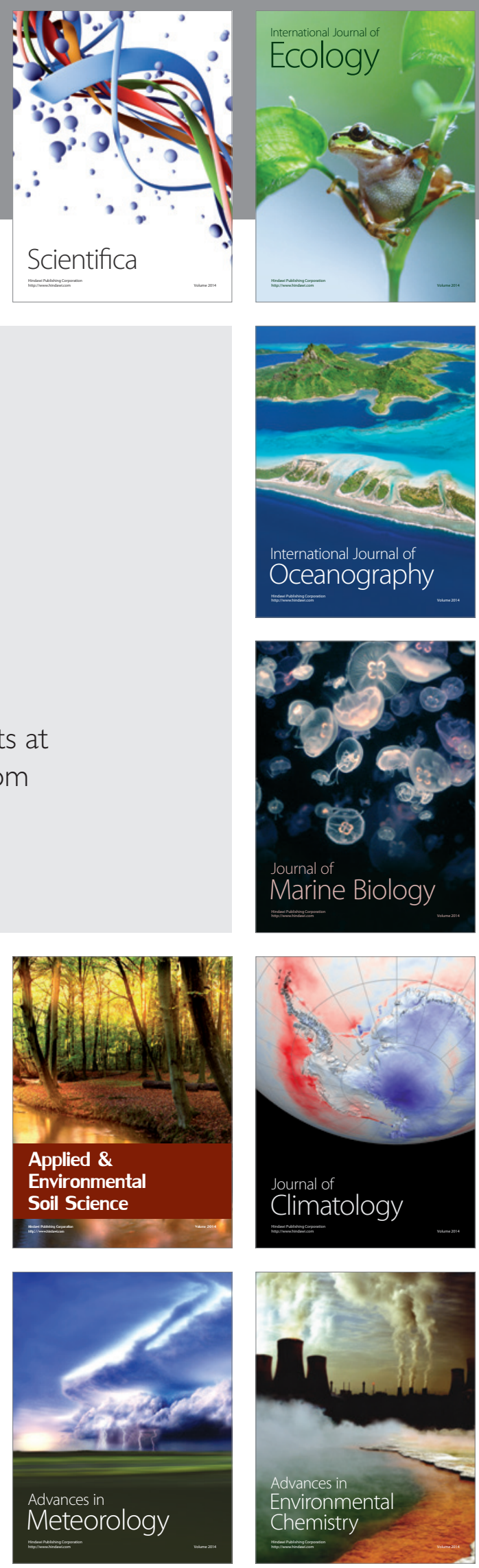